УДК 35.088(477)

DOI https://doi.org/10.32836/2310-9653-2020-3.9

\author{
Н. В. Піроженко, кандидат наук з державного \\ управління, доцент, доцент кафедри публічного \\ управління та регіоналістики Одеського регіонального \\ інституту державного управління Національної академії \\ державного управління при Президентові України
}

\title{
ТЕХНОЛОГІЯ «ТАЙМ-МЕНЕДЖМЕНТ» ЯК ІНСТРУМЕНТ ЧАСОВОЇ ОРГАНІЗАЦІЇ ПРОФЕСІЙНОЇ ДІЯЛЬНОСТІ ЧЛЕНІВ ТЕНДЕРНИХ КОМІТЕТІВ
}

У статті розглядаються теоретичні та практичні підходи до впровадження технології «управління часом», яка застосовується під час діяльності посадових осіб організацій, що здійснюють закупівлі державних закупівель, які є членами тендерних комісій, як інструмент тимчасової організації їх професійної діяльності. Встановлено, щяо державні закупівлі - ие форма економічних відносин на конкурентній основі між державою та постачальниками товарів, робіт та послуг, що має значні переваги для обох сторін. Проведення цього виду закупівель, засноване на принципах прозорості та конкуренції, не тільки економить гроші платників податків, але й приносить значні прибутки переможиям, які отримують контракти на поставку товарів, робіт чи послуг за значні обсяги державних коштів.

Автором виявлено низку проблем, які призводять до недоліків у роботі тендерних комісій, які можуть бути пов'язані з некомпетентністю управління часом у прочесі організації та проведення закупівель: швидкий темп змін законодавства у изій галузі; діяльність членів тендерного комітету в умовах чітко регламентованої форми та часових меж процедур закупівель, щзо створює емпіричну напругу, конфліктує з емоиійним досвідом та призводить до дезорганізації діяльності.

На основі аналізу нормативно-правового забезпечення державних закупівель та результатів їх впровадження в Україні доведено необхідність використання технологій «управління часом» як технології організаиї діяльності тендерного комітету та формування професійних та особистих компетениій ї̈ членів. Факторами, щчо визначають иъю потребу, є зростаючі темпи змін у соиіально-політичному та економічному середовищі, організаційно-правове забезпечення державних закупівель; постійні значні зміни в діяльності - розробка нових товарів, робіт та послуг, вихід на нові ринки, впровадження нових інструментів та систем управління тощз. Тому однією з головних иілей сучасного фахівия з держсавних закупівель останніми роками були: здатність ефективно організовувати час на будь-якому рівні-особистий, командний, корпоративний, а також вміння координувати свої дї з діями інших для виконання завдань.

Ключові слова: тайм-менеджмент, планування часу, управління часом, член тендерного комітету, публічні закупівлі, організація-замовник. activity

N. V. Pirozhenko. Technology of "time-management" as a tool of time organization of tender committees' professional

The article examines the theoretical and practical approaches to the introduction of "time management" technology which applied during the activities of officials of organizations procuring public procurement, which are members of tender committees, as a tool for temporary organization of their professional activities. It is established that public procurement is a form of economic relations on a competitive basis between the state and suppliers of goods, works and services, which has significant advantages for both parties. Conducting this type of procurement, based on the principles of transparency and competition, not only saves taxpayers money, but also brings significant profits to winners who receive contracts for the supply of goods, works or services for significant amounts of public funds.

Modern legislation in the field of public procurement requires rational and efficient spending of public funds, creating an environment of fair competition and combating corruption. Thus, the organizers of the procurement process must have the skills to adapt to the constantly changing environment, the willingness to independently acquire knowledge and think critically, to apply the acquired knowledge in practice.

During the investigation of reports of regulatory bodies on the analysis of public procurement - the Ministry of Economic Development, Trade and Agriculture of Ukraine and the State Audit Office of Ukraine, it is established that currently the main problem of modern public procurement practice is the "human factor".

A number of problems have been identified that lead to shortcomings in the work of tender committees, which may be related to incompetence in time management in the process of organizing and conducting procurement: the rapid pace of changes in legislation in this area; activity of members of the tender committee in the conditions of clearly regulated by form and time stages of procurement procedures, which creates empirical tension, conflicts with emotional experience and leads to disorganization of activity It is proved that recent legislative changes in public procurement in Ukraine, and vice versa-worsen it.

Based on the analysis of regulatory and legal support of public procurement and the results of their implementation in Ukraine, the need to use "time management" technologies as a technology for organizing the activities of the tender committee and the formation of professional and personal competencies of its members in the system of basic public procurement procedures. Factors that determine this need are the growing pace of change in the socio-political and economic environment, organizational and legal support

(C) Н. В. Піроженко, 2020 
of public procurement; constant significant changes in activities - development of new goods, works and services, entry into new markets, introduction of new tools and management systems, etc. Therefore, one of the main objective of the modern specialist in public procurement in recent years has been the ability to effectively organize time at any level-personal, team, corporate, as well as the ability to coordinate their actions with the actions of others to perform tasks.

Further research should focus on the study of specific tools for the introduction of "time management" technology in the activities of members of tender committees, identifying the benefits and risks of using these tools and methods of managing them.

Key words: time management, time planning, time management, member of the tender committee, public procurement, customer organization.

Постановка проблеми. У сучасних умовах динамічних змін соціально-політичної та економічної ситуації, зростання темпів надходження інформації, посилення конкуренції між організаціями і адміністративно-територіальними одиницями особливої важливості набуває управління таким ресурсом, як час.

Сьогодні він стає важливішим, ніж матеріально-технічні й фінансові ресурси, тому що наразі на перший план виходи здатність швидко і гнучко реагувати на будь-які непередбачені ситуації.

Зрозуміло, що швидка зміна навколишнього оточення й умов професійної діяльності тягнуть за собою збільшення обсягів завдань, що виконуються управлінцями і фахівцями, породжують необхідність пошуку резервів часу на реалізацію інноваційних проектів. Особливо гостро ці тенденції та завдання ефективного тайм-менеджменту постають перед членами тендерного комітету як суб'єктів організації та проведення публічних закупівель, що постійно працюють в умовах дефіциту часу, самовіддачі й певної напруженості, яка зумовлена специфікою вимог законодавства у даній сфері, частими змінами в ньому, труднощами планування роботи під час організації та проведення закупівель, вирішення великої кількості виникаючих складних ситуацій, особливо в умовах безперервних реформ.

Кожен з етапів закупівлі може потребувати негайного вирішення тендерним комітетом питань організації даного процесу, розв'язання конфліктів, розгляду вимог та скарг учасників, участі у термінових засіданнях комітету тощо. Ці проблеми дуже часто стають причинами гальмування процесу своєчасного прийняття відповідних рішень, а іноді призводять і до правопорушень .

Аналіз останніх досліджень і публікацій. Теоретико-методологічні особливості функціонування тайм-менеджменту, технології організації часу, методи його впровадження, способи застосування управління часом для розвитку і підвищення ефективності діяльності організації аналізуються в роботах таких авторів, як: Г.А. Архангельский, Ю. Забродіна, П. Фресса, П. Друкера, Р. Кастенбаума, Д. Нюттена, В. Денисова, Д. Завалішина, Г. Зараковського, В. Зінченко, В. Пономаренко та інших українських і зарубіжних вчених.

Зважаючи на сучасний стан розвитку науки, публічне управління та адміністрування, слід відзначити, що тайм-менеджмент як інструмент удосконалення часової організації професійної діяльності публічних службовців в окремих сферах, де його роль різко зростає, досі залишається недостатньо дослідженим.

Метою статті $\epsilon$ визначення та аналіз сучасних механізмів удосконалення часової організації професійної діяльності членів тендерних комітетів.

Виклад основного матеріалу. Публічні закупівлі є формою економічних відносин на конкурсних засадах між державою та постачальниками товарів, робіт і послуг, яка має суттєві переваги для обох сторін. Проведення публічних закупівель, що базуються на засадах прозорості та конкуренції, сприяє не тільки заощадженню коштів платників податків, а й приносить відчутний прибуток переможцям, котрі отримують контракти на постачання товарів, робіт чи послуг на значні суми державних коштів.

Сучасне законодавство у сфері публічних закупівель ставить перед його суб'єктами завдання раціонального та ефективного витрачання державних коштів, створення середовища добросовісної конкуренції та боротьби 3 проявами корупції, які здатні адаптуватися до змінних умов сьогодення, готові самостійно здобувати знання і критично мислити, застосовувати на практиці.

Із часів незалежності царина закупівель за державні кошти в Україні знаходиться в інтенсивній розбудові. Але тільки 12 лютого 2015 р. громадськості та ЗМІ було презентовано систему електронних закупівель «РroZorro». 2016 рік став роком кардинальних змін в системі публічних закупівель України. За останні роки в ній з'явилися низка технологічних рішень, вироблено принципово нову ідею взаємодії між державою, бізнесом та громадськістю, що була представлена в суспільстві тезою «Всі бачать все!». Реформа публічних закупівель в Україні була визнана однією з найуспішніших реформ 2016 року. Вона здобула значну підтримку як серед українців, так і з боку міжнародного товариства. Але, попри досить широке визнання, ця реформа - як і більшість реформ в Україні - зіштовхнулася зі значним опором та викликала палкі дискусії недовіри.

19.04.2020 року набрала чинності чергова нова редакція (третя з 2010 року) Закону України «Про публічні закупівлі». Відповідно до мети він покликаний зменшити ймовірну корупційну складову частину тендерів через посилення прозорості у їх проведенні, убезпечити замовників і виконавців від взаємних ризиків і захистити державу від нераціонального і неефективного витрачання коштів [7]. 
Згідно з пунктом 4 розділу X «Прикінцеві та перехідні положення» нової редакції Закону України «Про публічні закупівлі» замовник може утворювати тендерний комітет (комітети) для організації та проведення процедур закупівель, а також визначити уповноважену особу (осіб) та тендерний комітет (комітети), за умови що кожен із них буде відповідальним за організацію та проведення конкретних процедур закупівель [7].

Тендерний комітет є колегіальним органом. Це службові (посадові) та інші особи замовника, призначені відповідальними за організацію та проведення процедур закупівлі згідно із Законом.

На відміну від тендерного комітету, уповноважена особа (особи) - це службова (посадова) чи інша особа, що є працівником замовника і визначена відповідальною за організацію та проведення процедур закупівлі/ спрощених закупівель згідно з цим Законом на підставі власного розпорядчого рішення замовника або трудового договору (контракту). Саме принцип одноосібного прийняття рішень уповноваженою особою позбавляє їх діяльність багатьох організаційних проблем, що властиві тендерному комітету, хоча, слід відзначити, що породжує нові, такі як перевантаженість такого суб'єкта, певна кулуарність у процесі прийняття рішень під час організації та проведення закупівель тощо. Проте дослідження даної статті присвячене впровадженню технологій тайм-менеджменту в діяльність саме тендерного комітету, адже, окрім інших складностей виконання власних повноважень під час організації та проведення закупівель, жодне рішення в такому випадку не приймається одноосібно, а виключно колегіально на засіданнях тендерного комітету методом голосування та затверджуються відповідним протоколом.

Отже, відповідно ст. 11 базового Закону, тендерний комітет:

- планує закупівлі, складає та затверджує річний план закупівель;

- здійснює вибір процедури закупівлі;

- проводить процедури закупівель;

- забезпечує рівні умови для всіх учасників, об'єктивний та чесний вибір переможця;

- забезпечує складання, затвердження та зберігання відповідних документів з питань публічних закупівель, визначених цим Законом;

- забезпечує оприлюднення інформації та звіту щодо публічних закупівель відповідно до Закону;

- здійснює інші дії, передбачені Законом «Про публічні закупівлі» [7].

І все це окрім виконання основних обов'язків за місцем роботи і під тягарем персональної відповідальності за прійняті ними рішення, які члени комітету несуть відповідно до законів Україні.

А тому дуже своєчасним і актуальним є значне розширення новою редакцією Закону переліку порушень, за які притягуватимуться до адмінвідповідальності посадові особи та керівники замовників , а також збільшення суми штрафів за такі порушення:

- порушення процедур закупівель;

- оцінка пропозицій конкурсних торгів (кваліфікаційних пропозицій), тендерних пропозицій не за критеріями та методикою оцінки для визначення найкращої пропозиції конкурсних торгів (кваліфікаційної пропозиції), тендерної пропозиції, що міститься в документації конкурсних торгів (кваліфікаційній документації), тендерній документації;

- укладення з учасником, який став переможцем торгів, договору про закупівлю за цінами і обсягами, що не відповідають вимогам документації конкурсних торгів (кваліфікаційної документації), тендерної документації;

- неоприлюднення або порушення порядку оприлюднення інформації про закупівлі відповідно до вимог законодавства;

- ненадання інформації, документів та матеріалів у випадках, передбачених законом.

За це на службових (посадових), уповноважених осіб накладають штрафи в розмірі від 11900 грн. до 17000 грн. За повторне порушення - від 17000 грн. до 25500 грн. Вносено суттєві правки в ст.164 ${ }^{14}$ КУпАП, в якій вже вводиться певна градація щодо класифікації порушень та розміру штрафів за них. Так, за порушення порядку визначення предмета закупівлі; несвоєчасне надання або ненадання замовником роз'яснень щодо змісту тендерної документації; складання тендерної документації не відповідно до вимог закону тощо на службових (посадових), уповноважених осіб замовника накладатимуть штраф в розмірі 1700 грн. (3400 грн. $3 а$ повторне таке порушення) [7]

А ось, наприклад, за придбання товарів, робіт і послуг до/без проведення процедур закупівель / спрощених закупівель відповідно до вимог закону; невідхилення тендерних пропозицій, які підлягали відхиленню відповідно до закону; відхилення тендерних пропозицій на підставах, не передбачених законом або не у відповідності до вимог закону (безпідставне відхилення) тощо передбачено штраф в розмірі від 25500 грн. до 51000 грн.

Втім, жодної згадки про вдячність, мотивацію людей, які забов’язані забезпечити максимальну ефективність витрачання державних коштів! Позитивне вирішення даного питання залежить від доброї волі керівника замовника. У цьому аспекті цікавим є той факт, що Типове положення про тендерний комітет, яке втратило чинність 3 прийняттям в 2010 р. Закону «Про здійснення державних закупівель», містило норму, яка передбачала преміювання членів тендерного комітету. 
Крім того, Закон Ураїни «Про здійснення державних закупівель» в редакції 01.06.2010 р. передбачав обов'язок всіх членів комітету конкурсних торгів пройти навчання та/або підвищення кваліфікації спеціалістів у сфері здійснення державних закупівель у порядку, встановленому Міністерством економіки України.

3 моменту публікації даного закону, Міністерство економіки в ході реалізації адміністративної реформи вже було реарганізовано в Міністерство економічного розвитку та торгівлі, а наразі в Міністерство розвитку економіки, торгівлі та сільського господарства, проте наказу Уповноваженого органу порядку, що встановлював би вказаний порядок так і не було затвердженно.

Водночас в Україні бурхливі процеси у суспільстві та економіці рефлектують і на кількість та обсяг змін у законодавстві щодо публічних закупівель - з моменту прийняття Закону «Про публічні закупівлі» № 922-VIII від 25 грудня 2015 року було прийнято вже понад десяти законів, направлених на його вдосконалення. Відповідні зміни, зрозуміло, зазнають і інші законодавчі та підзаконні нормативно-правові акти інших ЦОВВ України, що задіяні в даному процесі (Міністерство роз-

\begin{tabular}{|c|c|c|}
\hline $\begin{array}{l}\text { Відповідно до нор.и } \\
\text { законодавспьа про публічні } \\
\text { закупівліу } 2017 \text { році уктадено } \\
\text { договорів на загальну су.иу, } \\
\text { з них: }\end{array}$ & 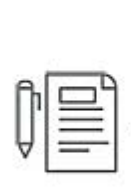 & 370,4.илрд. грн. \\
\hline $\begin{array}{l}\text { без застосубання процедур } \\
\text { закупівель на суиу }\end{array}$ & $\forall$ 抑哭 & 40,8.илрд. грн. \\
\hline $\begin{array}{l}\text { за конкуренпниии } \\
\text { процедурами проведено }\end{array}$ & 8 & 129056 закуиiбель \\
\hline за неконкуренпниии & 8 & 45371 закупікель \\
\hline 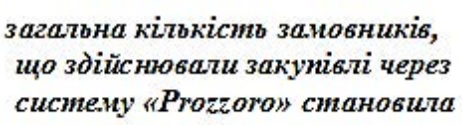 & =示亩 & $\begin{array}{l}14,6 \text { mис. } \\
\text { замобникік }\end{array}$ \\
\hline $\begin{array}{l}\text { застосовували допорогові } \\
\text { закупівлі }\end{array}$ & =二䍡 & $\begin{array}{l}25,6 \text { muс. } \\
\text { за.иовникіs }\end{array}$ \\
\hline
\end{tabular}

Рис. 1. Статистика публічних закупівель у 2017 році

витку економіки, торгівлі та сільського господарства України, Антимонопольного комітету України, Державної служби статистики України, Казначейської служби України тощо). Безумовно, всі ці зміни повинні бути об'єктом ретельного відстеження, аналізу та вивчення всіма членами комітету, адже разом з обов'язком пройти навчання персональну відповідальність за прийняті рішення з членів комітету ніхто не знімав.

Отже, цілком закономірним стали результати аналізу стану публічних закупівель в Україні у 2017 та 2018 роках, який засвідчив, що система закупівель була непродуктивною та не результативною - такий висновок зроблено Міністерством економічного розвитку та торгівлі України (наразі - Міністерство розвитку економіки, торгівлі та сільського господарства України) з огляду на те, що майже 74\% усіх замовників, на яких поширювалася дія Закону України «Про публічні закупівлі», не застосовували процедури торгів. Загальна статика публічних закупівель у 2017 році представлена на рис. 1 [4].

Головна проблема сучасної практики публічних закупівель - «людський чинник», що породжує корупцію і недобросовісність.

Відповідно до чинного до 19 квітня 2020 року законодавства, якщо річна вартість предмета закупівлі товару (товарів), послуги (послуг) є меншою 200 тисяч гривень, а робіт - 1,5 мільйона гривень, замовники не були зобов’язані проводити закупки в електронній системі публічних закупівель. Тобто якщо річна вартість предмета закупівлі не перевищувала порогових сум, організації-замовники мали право на його придбання без проведення конкурсних торгів, завантажуючи в систему «ProZorro» лише звіти про проведені закупівлі. Таким чином, створювалися умови для закупівлі товарів, робіт чи послуг у «свого улюбленого постачальника» без жодного натяку на конкуренцію та можливість перевірки ефективності і раціональності витрачання державних коштів під час закупівель із боку суспільства.

I не викликає здивування той факт, що даною можливістю успішно і активно користувались недобросовісні замовники. Це підтверджують результати звіту, який в було розроблено Міністерством економічного розвитку та торгівлі Украӥни. Статистичні дані сфери публічних закупівель, які охоплюють період з 1 січня по 31 грудня 2018 року (табл.1), показали стрімке збільшення (на 36\% порівняно з 2017 роком) кількості укладення прямих договорів організаторами закупівель без використання електронної системи [3].

На відміну від попередньої ситуації, нова редакція Закону вводить низку революційних змін щодо здійснення публічних закупівель в Україні, а саме: вимогу до замовників надавати звіт у систему ProZorro про всі закупівлі вартістю від 1 копійки. Таким чином, якщо річна вартість товарів, робіт і послуг не перевищує 50 тис. грн., тобто закупівлі здійснюються без використання електронної системи закупівель, то замовник обов'язково оприлюднює в електронній системі закупівель звіт про договір про закупівлю, укладений без використання електронної системи закупівель. Безумовно, такі зміни були необхідними і очікуваними, проте сподівання, що вони зможуть подолати корупційні схеми, виводячи з-під «ковдри таємничості» допорогові закупівлі, та відкриють можливості для участі в закупівлях новим учасникам, можуть виявитися марними. 
Діяльність учасників та організаторів в завершених закупівлях в 2018 році

\begin{tabular}{|c|c|c|c|c|c|c|}
\hline Процедура закупівлі & 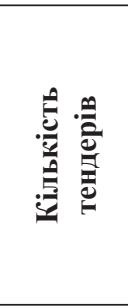 & 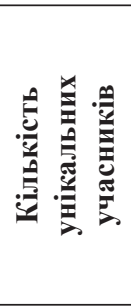 & 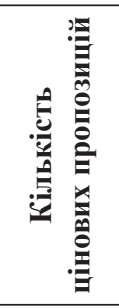 & 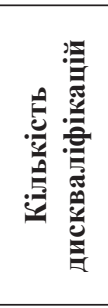 & 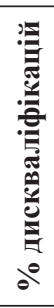 & 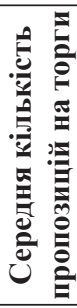 \\
\hline Всього & 251655 & 49275 & 621546 & 65131 & 10 & 2,28 \\
\hline Допорогова закупівля & 167174 & 30816 & 351639 & 31559 & 9 & 2,06 \\
\hline Відкриті торги & 78332 & 33254 & 244363 & 32398 & 13 & 2,66 \\
\hline Відкриті торги із публікацією англ. мовою & 4790 & 4696 & 20910 & 450 & 2 & 2,82 \\
\hline $\begin{array}{l}\text { Переговорна процедура } \\
\text { (для потреб оборони) }\end{array}$ & 1359 & 1045 & 4634 & 724 & 16 & 2,48 \\
\hline
\end{tabular}

Джерело: складено автором за даними МЕРТ України [3]

Бар'єром може стати знов таки ж незначний проміжок часу, що відведений законодавцем учасникам для участі в закупівлі - 5 робочих днів. Такі строки роблять участь новачків у тендері практично неможливою, адже саме за цей період вони повинні знайти оголошення про закупівлю, якісно та вчасно підготувати всі необхідні документи для подання тендерної пропозиції тощо. Отже, як участь у тендері, так і перемога в ньому стає найбільш ймовірною все ж таки для «своїх улюблених» постачальників.

Слід відзначити, що порушення законодавства у сфері публічних закупівель вчиняються майже на всіх стадіях даної процедури. За результатами перевірок Державною аудиторською службою України упродовж січня вересня 2019 року шляхом відміни торгів було попереджено порушень у сфері публічних закупівель на суму майже 9,7 млрд. грн. та розірвання договорів на суму понад 1,4 млрд. гривень [8]. Структура порушень, встановлених за результатами перевірок закупівель протягом січня-вересня 2019 року представлена на рис. 2.

Безумовно, не всі вони є наслідком саме корупційних діянь. Як показує практика, порушення в розміщенні замовлень і укладення контрактів певною мірою відбувається через неграмотність управлінського персоналу, нестачу часу тощо. У свою чергу, це потребує підготовки та формування професійного кадрового складу для системи закупівель. Але більшість із цих порушень допускається на стадіях підготовки документації та проведення тендерів. Порушення мають широке розповсюдження і по регіонах, і за галузями.

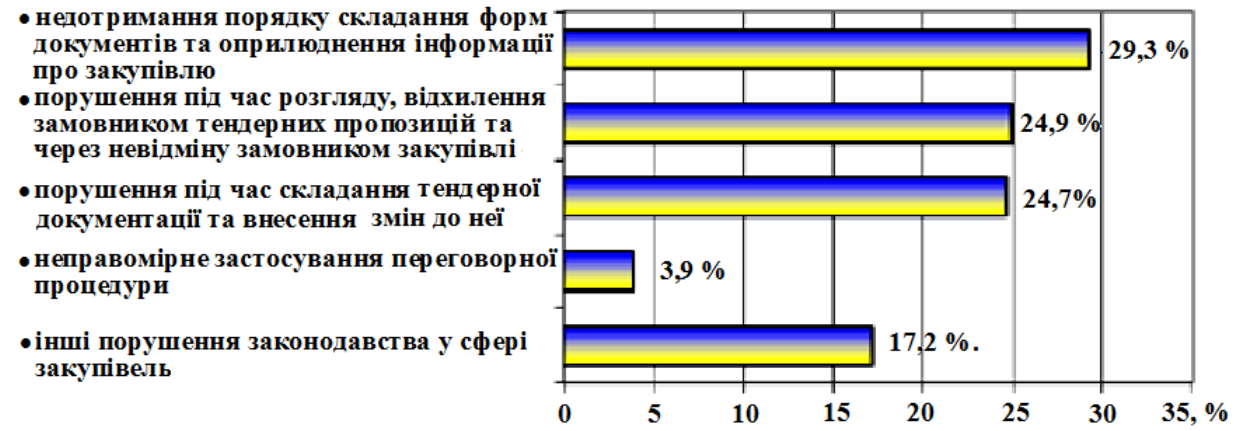

Рис. 2. Структура порушень за результатами перевірок закупівель Державною аудиторською службою України протягом 2019 року [3]

Питання державного регулювання даних закупівель у всьому світі є об’єктом пильної уваги з боку законодавців - адже в даному випадку сам покупець, тобто держава, зацікавлений в максимальній ефективності процесу. Якісна нормативна база і грамотне адміністрування закупівель сповна можуть звести можливі втрати ефективності до мінімуму. У даний час тайм-менеджмент $є$ одним з основних інструментів розвитку організації.

Ця необхідність проявляється в частині вивчення технології організаторської діяльності тендерного комітету та формування професійно-особистісних компетенцій його членів в системі основних процедур публічних закупівель. Актуальність окресленої проблематики підтверджується і з позиції психології. Швидкий темп змін в законодавстві даної сфери, діяльність членів тендерного комітету в умовах чітко регламентованих за формою і часом 
етапів процедур закупівель, що створює емпіричну напруженість, вступає в конфлікт з емоційним переживанням та призводить до дезорганізації діяльності комітету.

Управління часом дозволяє управлінцям керувати часом роботи, планувати, організовувати й оцінювати витрати на робочу силу на всіх етапах бізнес-процесів і мінімізувати витрати організації. Ресурсно-часова складова частина компетентності є важливою характеристикою стилю керівництва і трактується як здатність керівника оцінювати професійні можливості та психологічні ресурси підлеглих, правильно прогнозувати час для виконання того чи іншого завдання, а також результативність його виконання [2, с. 15]. Часова компетентність фахівця охоплює уміння: упорядковувати власні цілі; регулярно планувати власний час та правильно розставляти пріоритети; здійснювати делегування повноважень; застосовувати прийоми енергетичного самоменеджменту для оптимального співвідношення праці й відпочинку. Умовою формування цієї компетентності $€$ непохитність вольових рис характеру особистості (уміння долати труднощі, справлятися 3 непередбачуваними ситуаціями тощо) [5, с. 89]. Отже, ресурсно-часова компетентність означає адекватність сприйняття часу, володіння навичками планування часу, здатність раціонально перерозподіляти часові пріоритети та ліміти міжособистісного спілкування, дотримуватися принципів тайм-менеджменту, включаючи делегування повноважень у соціальних комунікаціях [1]. У спілкуванні часова компетентність визначає адекватність суб' єктивної оцінки часу і часового простору міжособистісної взаємодії, здатність до оптимальної взаємодії з урахуванням часових лімітів спілкування, емпатійність у розширенні або знятті часових меж комунікативного контролю [6, с. 51].

Таким чином, потреба у впровадженні тайм-менеджменту в діяльність членів тендерного комітету обумовлена наступними факторами:

1. Зростаючі темпи змін соціально-політичного та економічного середовища, організаційно-правового забезпечення публічних закупівель створюють умови, які вимагають виконання членами тендерного комітету значної кількості повноважень, оперативного та своєчасного, у відповідності з регламентом закупівельних процедур, прийняття ними колегіальних рішень, за які вони несуть персональну відповідальність, а також самостійна організація і планування своєї роботи як у тендерному комітеті, так і відповідно до посадових обов'язків.

2. Для організацій публічних закупівель стають нормою, а не рідкісним винятком, окрім законодавчих змін, постійні суттєві зміни діяльності - розробка нових товарів, робіт та послуг, вихід на нові ринки, впровадження нових інструментів і систем управління. Для членів тендерного комітету, відповідно, стає нормою постійне збільшення кількості та обсягу вирішуваних завдань, необхідність постійно вишукувати резерви часу для здійснення проектів, що дозволяють організації безперервно розвиватися.

Отже, технологія тайм-менеджменту може сприяти ефективному плануванню робочого часу членів тендерного комітету для досягнення цілей діяльності, знаходження часових ресурсів, розстановки пріоритетів і контролю за виконанням запланованого. Проблема управління часом значно ширша, ніж банальне складання графіка чи схеми виконання проекту.

Особливо гостро завдання ефективного тайм-менеджменту стоїть перед головами тендерних комітетів вони управляють не тільки своїм власним часом, а й робочим часом своїх підлеглих. Голова комітету організовує роботу комітету; приймає рішення щодо проведення засідань комітету; визначає дату і місце проведення засідань комітету; пропонує порядок денний засідань комітету; веде засідання комітету; уносить на розгляд керівника замовника пропозиції щодо змін у складі комітету; здійснює інші повноваження відповідно до законодавства. Таким чином, голова ранжує цілі й завдання, які він ставить перед своїми підлеглими, за ознакою «важливість-терміновість» для того щоб якомога швидше й ефективніше досягати поставленої мети.

Саме голова комітету планує загальний час (ресурс, який відводиться на досягнення конкретної мети) і вибирає завдання, які доцільно делегувати підлеглим. До речі, делегування повноважень - один з головних способів економії часу керівника. Бо єдиний шанс для керівника розвантажити себе і мотивувати людей - це передати відповідальність. Але для цього необхідно чітко поставити цілі, визначити критерії їх досягнення - інакше неможливо буде ні оцінити хід процесу, ні визначити, чи досягнуто результат.

Звісно, ідеальних технологій тайм-менеджменту, які б підходили всім і кожному, не існує. Тому запорука успішного управління часом - грамотне поєднання різних технологій і методик тайм-менеджменту. На сьогоднішній час тайм-менеджмент набув абсолютно нових форм та ознак, він став невід'ємною частиною не тільки ефективного управління підприємства загалом а й особистості зокрема. Саме тому проведене дослідження дає змогу використовувати його результати в діяльності тендерних комітетів організацій-замовників.

Висновки $з$ дослідження і перспективи подальших розвідок у цьому напрямі. Таким чином, ми можемо зробити узагальнений висновок, що основне проблемне питання публічних закупівель - зростаючі темпи змін вимагають від членів тендерного комітету прийняття великої кількості самостійних рішень, вміння самостійно організовувати і планувати свою роботу. Всі зростаючі зовнішні запити вимагають від них уміння самостійно розставляти пріоритети в умовах обмежених часових ресурсів. Тому одним з основних компетенцій сучасного фахівця з питань публічних закупівель останнім часом стало вміння ефективно організовувати час на будь-якому 
рівні - особистому, командному, корпоративному, а також здатність узгоджувати свої дії з діями оточуючих для виконання поставлених завдань.

Подальші дослідження потрібно сфокусувати на вивченні конкретних інструментів запровадження технології «тайм-менеджмент» у діяльності тендерних комітетів, виявленні переваг і ризиків під час застосування даного інструментарію та методів управління ними.

\section{Список використаних джерел:}

1. Болотова А.К. Психология организации времени : учебник. Москва : Аспект-Пресс, 2006. 254 с.

2. Борисюк О.М. Сутність та структура управлінської компетентності керівника. Проблеми екстремальної та кризової психологї : збірник наукових праџь. 2014. Вип. 16. С. 11-21.

3. Звіт, що містить аналіз функціонування системи публічних закупівель та узагальнену інформацію про результати здійснення контролю у сфері закупівель 2018 рік: / Міністерство економічного розвитку і торгівлі України. 2018. 33 c. URL : http://www.me.gov.ua/Documents/Detail?lang=uk-UA\&id=3befc2bd-57c1-4e5b-9d2ce36a1f624b8c\&title=ZvitSferiPublichnikhZakupivelZa2018-Rik.

4. Інформаційний ресурс Уповноваженого органу у сфері публічних закупівель. URL : http://me.gov.ua/ Documents/Detail?lang=uk-UA\&id=8245ceea- 6349-45c2-a2cf-35791699407f\&title=InformatsiiniiResurs.

5. Калинин С.И. Тайм-менеджмент: практикум по управлению временем. Санкт-Петербург : Речь, 2006. $371 \mathrm{c}$.

6. Підручна І.Б. Психологічні особливості часової компетентності особистості. Вісник Харківського націіонального університету імені В.Н. Каразіна. Серія «Психологія». 2012. № 1009. Вип. 49. С. 49-52.

7. Про публічні закупівлі : Закон України від 01 квіт. 2016 р. № 922-VIII: ред. від 19.04.2020 // Офіційний веб-сайт Верховної Ради України. URL : https://zakon.rada.gov.ua/laws/main/922-19.

8. Публічні закупівлі. Перезавантаження? // “Інтерфакс-Україна». URL : https://nv.ua/ukr/biz/experts.

\section{References:}

1. Bolotova A.K. (2006) Phycology of time management: tutorial. Aspect- Press. Moscow. 254 p. Russia.

2. Borisyuk O.M. (2014) Essence and structure of managerial competence. Problems of extreme and crisic psychology: a collection of scientific articles. Vol. 16. Pp. 11-21. [Ukraine].

3. Ministry of Economic Development and Trade of Ukraine. (2018). Report containing an analysis of the functioning of the public procurement system and generalized information on the results of control in the field of procurement in 2018. 33 p. Available at: http://www.me.gov.ua/Documents/Detail?lang= uk-UA\&id=3befc2bd-57c1-4e5b-9d2ce36a1f624b8c\&title=ZvitSferiPublichnikhZakupivelZa2018-Rik. [Ukraine].

4. Web resourse Authorized body in the field of public procurement Available at: http://me.gov.ua/Documents/ Detail?lang=uk-UA\&id=8245ceea- 6349-45c2-a2cf-35791699407f\&title=InformatsiiniiResurs. [Ukraine].

5. Kalinin S.I. (2006) Time management: manual of time handling. Rech. Saint Petersburg. 371 p. [Russia].

6. Pidruchna I.B. Psychological features of temporal competence of the individual. Bulletin of Kharkiv National University named after VN Karazina. Psychology series. 2012. № 1009. Vol. 49. C. 49-52. [Ukraine].

7. VRU (2016) About public procurement: Law of Ukraine 01.04.2016 № 922-VIII: New edition 19.04.2020 // Offisial web-site of Verkhovna Rada. Available at: https://zakon.rada.gov.ua/laws/main/922-19. [Ukraine].

8. Public procuremene. Reloading? “Interfax Ukraine” Available at: https://nv.ua/ukr/biz/experts. [Ukraine]. 